\title{
Frame Semantics in the Arabic Translation of Philosophical Terminology
}

\author{
Bahaa-eddin A. Hassan
}

\author{
Doi:10.5901/mjss.2017.v8n1p388
}

\section{Abstract}

The purpose of this study is to examine how philosophical terms are translated into Arabic. It aims at discussing the problems arising from the epistemological difference between Western philosophical terms and their counterparts in Arabic in the degree of reliance on cognitive frames. It focuses on the structure of terminological knowledge bases, which have a hidden network of semantic relations. Examples of the study are taken from the specialized encyclopedia of Abdel Rahman Badawi (1996). The study utilizes Frame-Based Terminology Theory to analyze the translation of the philosophical terms in the encyclopedia. The study argues that difficulties in translating philosophical terms represent epistemological barriers.

Keywords: Terminology, Translation, Arabic, Frame Semantics

\section{Introduction}

The question of untranslatability of philosophical terms is reflected by Willard Van Quine, the American philosopher, who asserts that "we cannot, in principle, provide translation rigorous enough to assess such grand philosophical theses" (Roger Hart, in press: 5). The translation of philosophical terms may be quite different from technical texts. Philosophers frequently invent their own terms. Parks (2004: 3) gives the example of Aristotle's works which seem untranslatable without paraphrase or without giving his terms additional meaning, to bring it closer to the original meaning of Aristotle's expressions. He gives the example of word 'eudaimonia' which is translated as 'happiness'. He states that "the alternative is to use the Greek term in English, requiring the reader to learn a new, foreign word to correspond to a foreign concept." (2004: 3)

The study deals with specialized language, i.e. philosophical texts. This type of specialized translation requires language skills and specialized knowledge in the field because terminological units possess both syntagmatic and paradigmatic structure. This study focuses on the paradigmatic structure, i.e. relationship between concepts assumed in one conceptual domain. Linguistic knowledge is not enough because a translator must consider the conceptual entities that the term is referring to. Faber (2009: 109) states that "in the understanding of the nature of terms, this process of meaning transmission is as important as the concept that they designate". The analysis of specialized terminology should be based on lexically-centered and concept-based approach. There is a shift to a cognitive and functional perspective of linguistic knowledge (Manerko 2007). The study goes in accordance with Faber's (2009) claim that beneath the term stretches a network of "conceptual domains, which represent the implicit knowledge underlying the information in the text" (2009:108).

In order to translate this type of specialized language text, translators must go beyond correspondences at the level of individual terms, and be able to establish interlinguistic references to entire knowledge structures. Only then can they achieve the level of understanding necessary to create an equivalent text in the target language. (2009: 108)

Therefore, terminology should be essentially considered within linguistic and cognitive perspective.

Meanings compose of concepts and are communicated in the form of terms. In other words, concepts use symbols (signs) which are the terms. Certain philosophical propositions are affirmed in one culture and denied in another. It is difficult to find a basis of comparison between philosophical terms; hence there is difficulty in identifying what is a good translation of a philosophical term. Some scholars view philosophical terms as untranslatable.

\section{Significance and Scope of the Study}

The study attempts to contribute to the discussion of translating philosophical terms into Arabic. It is significant because many translation studies ignore the question of translating Western philosophical terms into Arabic by Abdel Rahman Badawi, the Egyptian philosopher and academic who, was considered as "Egypt's first and foremost existential philosopher" (Encyclopedia Britannica). It shows how Abdel Rahman Badawi (1996) utilizes the cognitive frames to translate the Western philosophical terms into Arabic. The study focuses only on the Western philosophical terms in the 
encyclopedia. The encyclopedia is an Arabic text but it has multilingual terminology. It shows how Western philosophical terms are translated in Arabic. Badawi translated many books of philosophy into Arabic. He gathered all the philosophical terms in an encyclopedia of 1666 pages. The study attempts to illustrate some of the typical problems found in this field.

\section{Objectives of the Study}

The research problem for this study is to provide an account of the similarities and differences between the Western philosophical terms into Arabic. The study brings the literature on the various theories of terminology. It considers the nature of philosophical terms through the following research questions:

1. How are Western philosophical terms rendered into Arabic?

2. How can frame semantics be utilized in understanding the nature philosophical translation?

\section{Literature Review}

The translation of terminology has received scant attention in translation studies. Terminology as a discipline undergoes a period of theoretical vagueness. It has been for some time with no clear stable theory (Cabre' 2000: 169). Cabre' (2000: 169) points out that there has been a "lack of interest in terminology by specialists of other branches of science, for example, linguistics." There has been negligence of terminology in linguistics because "specialized language has been and is often regarded as merely a special case of general language" (Faber 2009: 110). In his book entitled Conceptology in Terminology Theory, Semantics and Word Formation, Peter Weissenhofer (1995), integrates prototype theory in the area of terminology. Oleksy and Stalmaszczyk (2009) show the many ways in which cognitive linguistics affected all fields of linguistics.

With regards to philosophy, most Western philosophical terms were produced in Greek, Latin, French and English. So the use of the Arabic language was not fully compatible with many western philosophical terms. However, some studies tackle Western philosophical concepts in Arabic. Arberry (1955) and Badawi (1955a; 1955b) discuss the Platonic thoughts in Arabic. Black (1990), Daiber (1997) and Brague (1999) deal with logic and Aristotle rhetoric in Arabic philosophy. The study is an attempt to cover the rendering of philosophical terms into Arabic.

\section{Data Collection and Methodology}

The data in the study are taken from the philosophical encyclopedia of Abdel Rahman Badawi (1996). Badawi is chosen as he was one of the prominent contemporary Arab philosophers. Badawi arranges the terms aphabetically in Arabic. The criterion for the selection of the terms is based on finding similarities and differences between the Western philosophical terms and their Arabic counterparts. The study begins with providing a theoretical framework defining terminology theories and then it moves to the discussion of the different techniques of translation. In describing the cognitive frames of the terms three criteria will be used:

1. similar frames

2. different frames

3. new frames

\section{Theoretical Framework}

\subsection{Terminology Theories}

Faber (2009) outlines a critical analysis of terminology theories with special reference to specialized translation. She points out that earlier theories of terminology were prescriptive rather than descriptive. Then, they undergo a cognitive, i.e. orientation to consider the cognitive perspective. She outlines 5 theories of terminology.

\subsubsection{General Terminology Theory (GTT)}

General Terminology Theory, which was developed by Wuster (1968), focuses on the standardization of scientific language. It attempts to account for the semantics of specialized language with no reference to other linguistic features. It concentrates on compiling terminological data with rigid view of semantics (Faber 2009: 111). It also excludes knowledge concepts from terminological description. "Concepts were conceived as abstract cognitive entities that refer to objects in 
the real world, and terms were merely their linguistic labels" (Faber 2009: 111).

Faber (2009: 112) criticizes GTT because "terminological variation is quite frequent, and that such variation seems to stem from parameters of specialized communication." She adds that "the same concept can often be designated by more than one term, and the same linguistic form can be used to refer to more than one concept" (2009: 112).

\subsubsection{Socioterminology}

This theory is proposed by Gaudin (1993). It acknowledges terminological variation. It is built on the social and situational aspects of specialized language communication. In other words, it accounts for "the knowledge, social and professional status of a group of users, as well as, the power relationship between nspeakers" (Faber 2009: 113).

\subsubsection{Communicative Theory of Terminology (CTT)}

Communicative Theory of Terminology stresses the view that terminology or the "specialized knowledge units are multidimensional, and have a cognitive component, a linguistic component, and and a sociocommicative component" (Faber 2009: 114). Cabre (2003: 184) introduces what she describes as "inter alia", or "particular knowledge area, conceptual structure, meaning, lexical and syntactic structure and valence, as well as the communicative context of specialized discourse" (Faber 2009: 114). Therefore, this theory includes cognitive component, linguistic component, and communicative component, but it does not propose any specific linguistic model $\mathrm{C}$ It also defines terminology as the special meaning of a lexical unit, but it does not explain the nature and component of specialized meaning (Faber 2009: 115).

\subsubsection{Cognitive-based Theory of Terminology}

The last theory is cognitive-based since linguistic theory undergoes a cognitive shift (Evans \& Green 2006). It has two models; a) Socio-cognitive Terminology, and b) Frame-based Terminology

a) Socio-cognitive Terminology

This model is based on Rosch's (1978) Prototype Theory in cognitive semantics. It is advocated by Tammerman (2000). It focuses on "the cognitive potential of terminology" (Faber 2009: 116). Faber (2009: 116) notices that such cognitive theories of terminology "have arisen in the context of translation" (2009: 116). Tammerman (2000) focuses terminology variation and emphasizes that categories and concepts should be studied diachronically. Socio-cognitive Terminology has the advantage of focusing on the concepts of category structure through prototype structure. Prototype theory uses degrees of typicality ranging from the good representation of a conceptual category or domain to the peripheral membership of domain. It shows series of "concentric circles with concepts placed intuitively either nearer or farther away from the prototypical centre" (Faber 2009: 118).

b) Frame-based Terminology

Frame-based terminology is outlined in (Faber et. Al. 2005; Faber et. Al. 2006; Faber et. al. 2007). It is based on Fillmore's Frame Semantics (Fillmore 1976, 1982, 1985; Fillmore and Atkins 1992). It enhances the concept of domain which refers to the knowledge area itself. Langacker (2000: 23) points out that 'domains' "represent the multiple realms of knowledge and experience evoked by linguistic expression" (Faber 2009: 122). In other words, it constitutes templates of concepts or what can be known as "terminology manual" (Faber 2009: 121).

Because the general function of specialized language texts is the transmission of knowledge, such texts tend to conform to templates in order to facilitate understanding, and are also generally characterized by a greater repetition than usual of terms, phrases, sentences, and even full paragraphs. This is something that specialized translators capitalize on when they use translation memories. (Faber 2009: 120)

This study dwells on Frame-based Terminology because it gives priority to the specialized concepts. A frame is "any system of concepts related in such a way that to understand any one concept it is necessary to understand the entire system" (Petruck 1996: 1). The idea can be exemplified by the commercial transaction frame, whose elements include a buyer, a seller, goods and money. Semantic frames can be interlingual representations of multilingual lexical database. The trend nowadays is to build a lexical database of hundreds of semantic frames. This model helps reveal information about conceptual structures in specialized language. It is also descriptive not prescriptive. It permits variation 
in terminology. It is also built on the concept of category. Frame-based Terminology emphasizes the relationship between language and thought. Faber (2009) stresses that it is "necessary to understand the concepts that linguistic forms designate. This is extremely important in any process of interlinguistic mediation, such as translation" (121-122). Framebased Terminology focuses on:

1. conceptual organization;

2. the multidimensional nature of terminological units; and

3. the extraction of semantic and syntactic information through the use of multilingual corpora (Faber 2009: 123)

This semantic framework of terminology is more adequate in handling problems in the translation of philosophical terms because one cannot understand the meaning of a single term without access to the essential knowledge that relates to that term. To explain the superiority of this model, Frame-based Terminology creates conceptual networks which are based on underlying domains, which generate templates of the actions and processes in the field as well as the entities that contribute to the field. In this model each terminology is characterized by a template with a set of conceptual relations.

The study uses Frame Semantics Theory as a theoretical framework because it is concept-oriented approach to terminology. According to Manerko (2014: 474), the term is not only a word but a concept-loaded lexeme. She points out:

The word is not thought as some kind of objective reality existing "in and for itself", it is shaped by our cognitive function including human perception, ability for categorization and conceptualization, interwoven with interpersonal experiences of human interaction. Linguistics takes into account all the sides of human factor in the language... (2014: 474).

Now, before moving to the analysis of data, it is appropriate to outline the translation techniques utilized to analyze the Western philosophical terms and their Arabic counterparts.

\subsection{Translation Techniques}

The study utilized 4 translation techniques adopted from (Vinay and Darplent 1958); equivalence, modulation, calque and cultural borrowing. They classify cultural borrowing, literal translation and calque as direct translation techniques; and equivalence and modulation as oblique translation techniques. Literal translation is the reproduction of the source text form. Borrowing is the process of taking words directly from one language into another without translation. A calque or loan translation is a phrase borrowed from another language and translated literally word for word. Oblique translation techniques are used when the conceptual elements of the source language cannot be directly rendered without altering meaning. Modulation refers to using a phrase that is different in the source and target languages to convey the same idea. It changes the semantics and shifts the point of view of the source language. Through modulation, the translator generates a change in the point of view of the message without altering meaning. In equivalence the translator expresses something in a completely different way.

The study argues that translation techniques used in philosophical terms are related to the cognitive frames of the terms. To settle on reference criteria dealing with the translation of philosophical terms, the study proposes that

1. In case of similar frames, an oblique technique (equivalence) is used

2. In case of different frames, an oblique technique (modulation) is used

3. In case of new frame, a direct technique (literal translation, cultural borrowing or calque) is used

4. The study assigns the translation technique according to the type of terminology.

\section{Analysis}

Let us now start analysis of data to recognize what options a translator has for handling potentially. Frame elements are words associated with it and used in understanding the frame (Fillmore 1985).

\subsection{Similar Frames}

Western philosophical terms can be defined in a number of different ways. Some terms in English, French or Latin have similar frames with their Arabic counterparts. For example, terms such as liberty, phenomentalism, theism, substratum, induction and deduction have the same conceptual meaning in Arabic translation. 
Table 1: Similar Semantic Frame of the Term 'Liberty'

\begin{tabular}{|c|c|c|c|c|}
\hline Western Term & Arabic Translation & Frame & Frame elements in English & Frame elements in Arabic \\
\hline $\begin{array}{c}\text { Liberty (En) } \\
\text { Liberte' (Fr) (p.458) }\end{array}$ & الحرية & Human rights & $\begin{array}{l}\text { Freedom, } \\
\text { rights }\end{array}$ & تحتق \\
\hline
\end{tabular}

Table 2: Similar Semantic Frame of the Term 'Phenomenalism'

\begin{tabular}{|c|c|c|c|c|}
\hline Western Term & Arabic Translation & Frame & Frame elements in English & Frame el \\
\hline Phenomena & الظو اهرية & Existence & Physical object, perception & الثئ الماد \\
\hline
\end{tabular}

Table 3: Similar Semantic Frame of the Term 'Theism'

\begin{tabular}{|c|c|c|c|c|}
\hline Term & Arabic Translation & Frame & Frame elements in English & Frame elements in Arabic \\
\hline Theism (p.627) & التأليهية ، مذهب المؤلهة & belief & God & إله بوجود الإيمان باله ، الإيمان \\
\hline
\end{tabular}

Table 4: Similar Semantic Frame of the Term 'Substratum'

\begin{tabular}{|c|c|c|c|c|}
\hline Western Term & Arabic Translation & Frame & Frame elements in English & Frame elements in Arabic \\
\hline Substratum (p. 290) & الجوهر ، أساس & entity & substratum & \\
\hline
\end{tabular}

Table 5: Similar Semantic Frame of the Term 'Induction'

\begin{tabular}{|c|c|c|c|c|}
\hline Western Term & Arabic Translation & Frame & Frame elements in English & Frame elements in Arabic \\
\hline Inducti & استقر اء & Judgment & Inference & استنباط \\
\hline
\end{tabular}

Table 6: Similar Semantic Frame of the Term 'Deduction'

\begin{tabular}{|c|c|c|c|c|}
\hline Western Term & Arabic Translation & Frame & Frame elements in English & Frame elements in Arabic \\
\hline Deduction (p. 145) & Julgment & conclusion & استخلاسى استخلاص \\
\hline
\end{tabular}

It is noticed that the indirect technique of translation, i.e. equivalence, is used to render philosophical terms with similar conceptual frames or structures.

\subsection{Different Frames}

Western philosophical terms which are different from Arabic terms are rendered in a different way. In fact, many Western philosophical concepts permeated the Arabic philosophical repertoire. Arabic philosophers add their own ideas to Western philosophies. There are unquestionably differences and incommensurable elements between the Western philosophy and the Islamic philosophy. The concept of eternity in Arabic, for example, has contextual meanings embedded in the Islamic traditions, which may induce differences of what Western philosophy refers to. This is not only a kind of difference in terminologies, but also relates to differences in the epistemological frames. The Islamic philosophy has an integrated and consisted idea of the Creator and the Universe. The Western philosophy has a various ideas of theology. In terms of translation techniques, modulation helps to illustrate the difference between source language meaning and the target language meaning. The idea is the same, but the phrases that are used in the source and target languages are different Notice modulation is utilized in rendering the following terms:

Table 7: Different Semantic Frame of the Term 'Atheism'

\begin{tabular}{|c|c|c|c|c|}
\hline Western Term & Arabic Translation & Frame & Frame elements in English & Frame elements in Arabic \\
\hline Atheism (p. 219) & الالحاد & belief & No god & زندقة \\
\hline
\end{tabular}

The English term atheism is derived from the prefix a 'without' and the root theo 'God'. There is no complete equivalence 
between the English term and the Arabic translation. The word 'الحاد' literally means 'deviation'. Another example is the term "eternity".

Table 8: Different Semantic Frame of the Term 'Eternity'

\begin{tabular}{|c|c|c|c|c|}
\hline Western Term & Arabic Translation & Frame & Frame elements in English & Frame elements in Arabic \\
\hline Eternity (p.574) & السرمدية & Time duration & Eventuality, period & الآخر \\
\hline
\end{tabular}

The term 'eternal' in English is used to mean lasting or existing forever, without end or beginning (merriam-webster

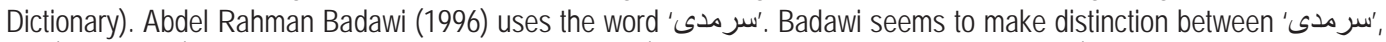
'أبدى' 'أزلى'. He justifies his choice; the word 'أبدى' denotes no end and the word 'أبردى' denotes no beginning in

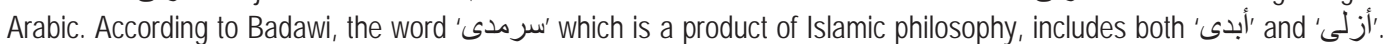
The study argues that there are two different epistemological frames; that of the western philosophy and that of the Islamic philosophy. Differences in language then serve as a natural symbol for this conceptual split.

Differences between English and Arabic express different world views. There is difference between the Western philosophy and the Islamic philosophy in the fundamental concept of 'being' and 'existence'. Theological meaning affects the way how the philosophical term is translated.

Table 9: Different Semantic Frame of the Term 'Mystery'

\begin{tabular}{|c|c|c|c|c|}
\hline Western Term & Arabic Translation & Frame & Frame elements in English & Frame elements in Arabic \\
\hline Mystery (p.223) & الوجود القيمة & Existence & Doctrine, divine & الهُ \\
\hline
\end{tabular}

Another term with a different philosophical meaning is the word intuition. Badawi does not translate it as "الحسب" or as "الظن". He translates as "الوجدان".

Table 10: Different Semantic Frame of the Term 'Intuition'

\begin{tabular}{|c|c|c|c|c|}
\hline Western Term & Arabic Translation & Frame & Frame elements in English & Frame elements in Arabic \\
\hline Intuition (p. 325) & الوجدان ، العيانة & perception & Sense & بديهة \\
\hline
\end{tabular}

Notice also how the term 'intuitive knowledge' is rendered.

Table 11: Different Semantic Frame of the Term 'Intuitive Knowledge'

\begin{tabular}{|c|c|c|c|c|}
\hline Western Term & Arabic Translation & Frame & Frame elements in English & Frame elements in Arabic \\
\hline $\begin{array}{c}\text { Scientia intuitive (Latin) (p. 142) } \\
\text { (Intuitive Knowledge) }\end{array}$ & المعرفة العيانية غليقة & perception & innate & \\
\hline
\end{tabular}

The term 'scientia intuitive' is translated into English as 'intuitive knowledge'. The Latin word scientia has a much stricter sense of knowledge. In Aristotle's usage, much that he calls a 'science' is what we would term a body of knowledge. The following example is the word 'Demiurge' which literally means "الصانع". Badawi renders the term as "منظم الكون".

Table 12: Different Semantic Frame of the Term 'Demiurge'

\begin{tabular}{|c|c|c|c|c|}
\hline Western Term & Arabic Translation & Frame & Frame elements in English & Frame elements in Arabic \\
\hline Demiurge (p. 45) & creation & Creator, God & $\begin{array}{c}\text { الخظم الكون } \\
\text { الخانق }\end{array}$ \\
\hline
\end{tabular}

Another example is the term 'alienation'. It is rendered as "الابتعاد عن الله”. 
Table 13: Different Semantic Frame of the Term 'Alienation'

\begin{tabular}{|c|c|c|c|c|}
\hline Western Term & Arabic Translation & Frame & Frame elements in English & Frame elements in Arabic \\
\hline Alienation (p.450) & الابنعاد عن الهاد & Belief & Isolation, alienated & إغتراب \\
\hline
\end{tabular}

\subsection{New Frames}

When the philosophical term is completely different, only direct techniques can be used. They can be literal translation, cultural borrowing or calque. The following two terms 'Transcendentalism' and 'Teleology' are literally translated into Arabic since they have new conceptual frames to the Arabic philosophical repertoire.

Table 14: New Semantic Frame of the Term 'Transcendentalism'

\begin{tabular}{|c|c|c|c|c|}
\hline Western Term & Arabic Translation & Frame & Frame elements in English & Frame elements in Arabic \\
\hline Transcendentalism (p. 591) & الفلسفة المنعالية & philosophy & $\begin{array}{c}\text { Thought } \\
\text { Reasoning } \\
\text { Human knowledge }\end{array}$ & مذهب السامى التعى \\
\hline
\end{tabular}

The word 'Teleology' is translated literally as it is derived from Greek telos, meaning end or purpose.

Table 15: New Semantic Frame of the Term 'Teleology'

\begin{tabular}{|c|c|c|c|c|}
\hline Western Term & Arabic Translation & Frame & Frame elements in English & Frame elements in Arabic \\
\hline Teleology (p.80) & philosophy & purpose & $\begin{array}{c}\text { الغائية } \\
\text { الغنفية }\end{array}$ \\
\hline
\end{tabular}

Cultural borrowing or transliteration, as a direct technique, follows the phonetic rules of the target language. Transliterated words are often naturalized to assimilate the structure of the target language. Translators introduce minor phonetic and morphological changes to the foreign term (Ghazzala 1995). Notice how the following words are rendered.

Table 16: New Semantic Frame of the Term 'Gnosticism'

\begin{tabular}{|c|c|c|c|c|}
\hline Western Term & Arabic Translation & Frame & Frame elements in English & Frame elements in Arabic \\
\hline Gnosticism (p. 450) & الغنوصبة & perception & $\begin{array}{c}\text { Divine knowledge, } \\
\text { Gnosis }\end{array}$ & مذهب العنرفانة \\
\hline
\end{tabular}

The word Gnosticism means having knowledge or salvation or enlightenment. It is naturalized in Arabic as "الغنوصية". The word 'Totemism' is also naturalized in Arabic.

Table 17: New Semantic Frame of the Term 'Totemism'

\begin{tabular}{|c|c|c|c|c|}
\hline Western Term & Arabic Translation & Frame & Frame elements in English & Frame elements in Arabic \\
\hline Totemism (p. 483) & Religion & $\begin{array}{c}\text { Mystical } \\
\text { totem }\end{array}$ & $\begin{array}{c}\text { bائفية } \\
\text { Tot }\end{array}$ & الطومية \\
\hline
\end{tabular}

Calque, as a direct technique, is sometimes utilized. It is used for example to translate the term 'agnosticism' as "اللأدرية".

Table 18: New Semantic Frame of the Term 'Agnosticism'

\begin{tabular}{|c|c|c|c|c|}
\hline Western Term & Arabic Translation & Frame & Frame elements in English & Frame elements in Arabic \\
\hline Agnosticism (p.450) & اللادرية & perception & Disbelief in God & الكفر \\
\hline
\end{tabular}


The next word 'solipsism' is also an example of calque. It is derived from Latin solus, meaning "alone", and ipse, meaning "self". It is translated as "لهووحدية".

Table 19: New Semantic Frame of the Term 'Solipsism'

\begin{tabular}{|c|c|c|c|c|}
\hline Western Term & Arabic Translation & Frame & Frame elements in English & Frame elements in Arabic \\
\hline Solipsism (p. 523) & الهووحدية & philosophy & $\begin{array}{c}\text { Self } \\
\text { egoism }\end{array}$ & \begin{tabular}{l} 
الأنان \\
\hline
\end{tabular} \\
\hline
\end{tabular}

Notice also the following example.

Table 20: New Semantic Frame of the Term 'Intersubjectivity'

\begin{tabular}{|c|c|c|c|c|}
\hline Western Term & Arabic Translation & Frame & Frame elements in English & Frame elements in Arabic \\
\hline Intersubjectivity (p.546) & ما بين الذوات ذاتية & Education & interdisciplinary & منتر \\
\hline
\end{tabular}

From the previous examples the study summarizes the following points: First, philosophical texts have special nature; they contain highly sophisticated ideas. They are also different from other texts, in which ideas seem simple and clear. Philosophical texts usually stem from the mind and heading to the mind. The author of a philosophical text was not moving normally to the average reader, or even average, but to a special reader who deals with philosophy away from the community. Second, philosophical texts contain exotic terms, and they are unfamiliar to the Arab reader. Badawi followed a more cognitive approach in translating philosophical terms. He reformulated many Western terms within the Arabic epistemological frame.

\section{Conclusion}

The study attempts to survey the different theories if terminology and favors Frame Semantics as it adds a cognitive dimension to linguistics. In order to understand the meanings of terminology in specialized language, one must first have knowledge of the semantic frames or conceptual structure that underlies their usage. Regardless of the linguistic differences, the study asserts that conceptual differences do exist. Therefore, frame semantics which is based on the conceptual structure of the word play an important role in understanding the philosophical terminology.

The study also asserts the correlation between the conceptual frames of the philosophical terms and the translation techniques used in rendering them into Arabic. In case of similar epistemological frames, the indirect technique (equivalence) is used. In case of different epistemological frames, the indirect technique (modulation) is used. And when there is a new epistemological frame, a direct technique (literal translation, cultural borrowing or calque) is used.

\section{References}

Arberry A. J., 1955. "Some Plato in an Arabic Epitome", The Islamic Quarterly 2, 86-99.

Badawi, A., 1955a. Aflutin 'inda I-'arab. Plotinus apud Arabes. Theologia Aristotelis et fragmenta quae supersunt, Maktabat al-Nahda alMisriyya, Cairo 1955 (repr. Dar al-Nahda al-Misriyya, Cairo 1966).

Badawi, A. 1955b. Al-Aflatuniyya al-muhdatha 'ind al-'Arab, Maktabat al-Nahda al-Misriyya, Cairo 1955 (repr. Wikalat al-Matbu'a, alKuwayt 1977).

Badawi, A. 1996. Encyclopedia of philosophy. Beirut: Arab Institution for studies and Publication.

Black, D.L. 1990. Logic and Aristotle's Rhetoric and Poetics in Medieval Arabic Philosophy, Brill, Leiden.

Brague, R. 1999. Thémistius. Paraphrase de la Métaphysique d'Aristote (livre Lambda), traduit de l'hébreu et de l'arabe, int., notes et indices par R. Brague, Vrin, Paris.

Cabré, C. 2000. "Elements for a theory of terminology: Towards an alternative paradigm". Terminology 6(1), 35-57.

Cabré, C. 2003. "Theories of terminology: their description, prescription and explanation". Terminology 9(2). pp. 163-199.

Daiber, H. 1997. "Salient trends of the Arabic Aristotle", in The Ancient Tradition in Christian and Islamic Hellenism. Studies on the Transmission of Greek Philosophy and Sciences dedicated to H.J. Drossaart Lulofs on his ninetieth birthday, ed. by G. Endress and R. Kruk, Leiden, 29-41.

Encyclopedia Britannica, "Abdel Rahman Badawi", Available online: https://global.britannica.com/biography/Abdel-Rahman-Badawi

Evans, V. \& M. Green. 2006. Cognitive linguistics: An introduction. Edinburgh: Edinburgh University Press.

Faber, P. 2009. The cognitive shift in terminology and specialized translation. MonTI, no. 1: 107-134. 
Faber, P., Arauz, P., Velasco, J. \& Reimerink, A. 2007. "Linking images and words: the description of specialized concepts". International Journal of Lexicography 20,39-65.

Faber, P.; C. Marquez Linares \& M. Vega Exposito. 2005. "Framing Terminology: A Process-Oriented Approach". META 50 (4). CDROM.

Faber, P.; S. Montero Martinez; M. R. Castro Prieto; J. Senso Ruiz; J. A. Prieto Velasco; P. Leon Arauz; C. Marquez Linares \& M. Vega Exposito. 2006. "Process-oriented terminology management in the domain of Coastal Engineering". Terminology 12:2. pp. 189213.

Fillmore, C. J. 1976. "Frame semantics and the nature of language". In S. R. Harnad, H. D. Steklis \& J. Lancaster (eds.) Origins and Evolution of Language and Speech, (20-32) Annals of the NY Academy of Sciences, 280.

Fillmore, C. J. 1982. "Frame semantics". In: The Linguistic Society of Korea (ed.) Linguistics in the Morning Calm. Seoul: Hanshin. pp. 111-137.

Fillmore, C. J. 1985. "Frames and the semantics of understanding". Quaderni di Semantica. 6 (2). pp. 222-254.

Fillmore, C. J. \& S. Atkins. 1992. "Towards a frame-based organization of the lexicon: The semantics of RISK and its neighbors". In A. Lehrer \& E. Kittay (eds.) Frames, Fields, and Contrast: New Essays in Semantics and Lexical Organization. (75-102) Hillsdale, $\mathrm{NJ}$ : Lawrence Erlbaum.

Gaudin, F. 1993. Pour une socioterminologie: Des problèmes pratiques aux pratiques institutionnelles. Rouen: Publications de I'Université de Rouen.

Ghazala, H. 1995. Translation as problems and solutions: A course-book for university students and trainee translators. Valetta Malta: Elga Publication.

Hart, R. In Press. "Translating the Untranslatable: From Copula to Incommensurable Worlds". To appear in Tokens of Exchange: The Problem of Translation in Global Circulations, edited by Lydia H. Liu. Durham, N.C.: Duke University Press (in press); an earlier version is being published as "Translating Worlds: Incommensurability and Problems of Existence in Seventeenth-Century China," Positions 7, no. 1 (in press).

Langacker, R. W. 2000. Cognitive Grammar: An Introduction. Oxford: Oxford University Press

Manerko, L. 2014. Concept understanding in cognitive linguistics and cognitive terminology science. In G. Budin \& V. Lušicky (eds.), Languages for Special Purposes in a Multilingual, Transcultural World, Proceedings of the 19th European Symposium on Languages for Special Purposes, 8-10 July 2013, Vienna, Austria. Vienna: University of Vienna, 471-483.

Manerko L. 2007. Cognitive Aspect of Terminology Description as a Means to Understanding Specialised Discourse. The XVIth European Symposium on Language for Special Purposes (LSP) "Specialised Language in Global Communication": Book of Abstracts. Hamburg, 2007. P. 118-119.

Oleksy, W. and S. Piotr (eds.) 2009. Cognitive Approaches to Language and Linguistic Data: Studies in honor of Barbara LewandowskaTomaszczyk Series: Polish Studies in English Language and Literature - Volume 27. Frankfurt am Main, Berlin, Bern, Bruxelles, New York, Oxford, Wien, 2009. 527.

Parks, G. 2004. "The translation of philosophical texts". Rivista internazionale di tecnica della traduzione: 8, 1-10

Petruck, M. 1996. "Frame Semantics". In J. Verschueren, J.-O. Ostman, Handbook of Pragmatics, Amsterdam: Benjamins, 1-13

Rosch, E. 1978. "Principles of categorization". In E. Rosch \& B.B. Lloyd (eds.) Cognition and Categorization. Hillsdale, N.J: Erlbaum. pp. $27-48$

Temmerman, R. 2000. Towards New Ways of Terminology Description. Amsterdam/ Philadelphia: John Benjamins.

Vinay, J.-P. et Darbelnet, J. 1960. Stylistique comparée du français et de l'anglais.. In: Revue belge de philologie et d'histoire, tome 38, fasc. 2, Histoire (depuis la fin de l'Antiquité) — Geschiedenis (sedert de Oudheid) pp. 451-452.

Weissenhofer, P. 1995. Conceptology in terminology theory, semantics and word-formation: a morpho-conceptually based approach to classification as exemplified by the English baseball terminology. Vienna : TermNet,

Wüster, E. 1968. The Machine Tool. An interlingual dictionary of basic concepts. London: Technical Press. 